\title{
Customer satisfaction/delight and behavioural intentions of cell phone network customers - an emerging market perspective
}

\author{
Mornay Roberts-Lombard \\ Marketing Management, \\ University of Johannesburg - Auckland Park Kingsway Campus, \\ Johannesburg, South Africa, and \\ Daniël Johannes Petzer \\ University of Pretoria Gordon Institute of Business Science, \\ Johannesburg, South Africa
}

\begin{abstract}
Purpose - The study investigates the extent to which the satisfaction/delight experienced by customers of cell phone network service providers is influenced by their perceptions of the networks' employee service delivery skills and the value that the customers derive from the networks' offerings. In turn, the influence of the extent of their satisfaction/delight on future behavioural intention is determined.
\end{abstract}

Design/methodology/approach - An descripto-explanatory research design was followed and data was collected from satisfied/delighted cell phone network service provider customers using self-administered questionnaires. A total of 593 responses were suitable for analysis. An exploratory factor analysis was used to uncover the interrelationships between the items measuring the study's constructs. Furthermore, the measurement and structural models were assessed.

Findings - Perceived employee service delivery skills and value significantly and positively influence customer satisfaction/delight experiences, while customer satisfaction/delight experiences significantly and positively influence their behavioural intentions.

Research implications - The model tested confirms the hypothesised relationships between perceived employee service delivery skills, perceived value, customer satisfaction/delight experiences and behavioural intentions of cell phone network customers. Customer satisfaction/delight experiences are linked to their two antecedents (perceived employee service delivery skills and value) and their outcome, behavioural intention.

Managerial implications - The findings assist cell phone network service providers in understanding how perceived employee service delivery skills and value can foster customer delight, ultimately leading to positive behavioural intentions from customers.

Originality/value - The study focused only on satisfied customers and determined the interrelationships of the extent to which they encounter customer satisfaction/delight 
experiences and related constructs. Few research studies, however, have examined how customer satisfaction/delight experiences relate to the antecedents and outcome.

Keywords Perceived employee service delivery skills, Perceived value, Customer satisfaction, Customer delight, Customer satisfaction/delight experiences, Behavioural intention, Cell phone network service provider

\section{Paper type Research paper}

This work is based on research supported in part by the National Research Foundation of South Africa (Grant Number: 104662).

Disclaimer:

Any opinion, finding and conclusion or recommendation expressed in this material is that of the authors and the National Research Foundation of South Africa does not accept any liability in this regard.

\section{Introduction}

Satisfying the needs of customers is not enough to retain customers over the long term (Trasorras et al., 2009); therefore service providers often build in switching costs to retain their customers (Lam, Shankar, Erramilli and Murthy, 2004). Relying solely on this approach often proves counterproductive, as customers simply remain with the service provider only to avoid the costs of severing the relationship and not always out of their own free will, resulting in negative consequences for service providers, especially if customers are dissatisfied, such as with their spreading negative word-of-mouth (Lee and Neale, 2012). Matzler, Strobl, Thurner and Füller (2015) further profess that switching costs impact negatively on customer satisfaction and customers' behavioural intention. Instead of relying primarily on switching costs, creating customer delight or "going beyond satisfaction" (Torres and Kline, 2013), is often cited as a way service providers can retain customers and positively impact on customers' future behavioural intentions (Liu and Keh, 2015).

Numerous research studies have investigated the interrelationships between customers' level of satisfaction, its antecedents such as service experience perceptions and perceived value as well as a possible outcome, namely behavioural intention in different contexts and service settings. Few research studies have, however, examined how customer delight relates to its antecedents and outcome. Customer delight is also a relatively novel construct and has generally received little attention as a relational determinant (Bowden-Everson, Dagger and Elliott, 2013).

In this study customer delight was considered as an elevated level of customer satisfaction (Torres and Kline, 2013; Füller and Matzler, 2008). Based upon the work of Berman (2005) who focussed on differentiating between the attributes of customer satisfaction and delight, a scale was developed to measure the extent of customer delight and satisfied customer experience on a continuum where customer satisfaction is 
represented on the one end, and customer delight on the other (customer satisfaction/delight). The customers' service experience perceptions, value perceptions and behavioural intentions towards a cell phone network service provider in an emerging market context were also studied, and how these constructs relate to one another. The study aimed at determining the extent to which the delight experienced by customers of cell phone network service providers is influenced by their perceptions of the networks' employee service delivery skills and the value they derive from the networks' offerings. In turn, the influence of the extent of their delight on future behavioural intention was determined.

The study contributes to theory since it indicates that the previously identified relationships between customer satisfaction and its antecedents and outcome are also evident between the customer satisfaction/delight experiences construct and these antecedents and outcome in an emerging market context. A model was proposed and verified that illustrates the $\mathrm{B} 2 \mathrm{C}$ relationships between customer satisfaction/delight experiences, its antecedents and behavioural intention within a South African cell phone network service provider context. From a managerial perspective, the study contributes in potentially assisting cell phone network service providers in understanding how perceived employee service delivery skills and value can foster customer delight, ultimately leading to positive behavioural intentions from customers.

This paper provides an overview of the context within which the study is set. This is followed by an exposition of the theories grounding the study and an explanation of the key constructs of the study. The hypotheses for the study are presented and a theoretical model is proposed. The research methodology is followed by the results, the findings and the managerial implications of the study.

\section{Theoretical framework}

\section{Cell phone network service providers in South Africa}

The South African cell phone market can be characterised as having one of the fastest growth rates in the world since cell phone services were introduced to South Africa in 1994 (Bendi, 2016). The use of cell phones by South Africans increased from 17\% having cell phones in 2000 to $82 \%$ owning cell phones in 2015. In 2016, a total of 35 million South Africans were using cell phones, with the dominant cell phone network service providers in the market being MTN (approximately 29.1 million subscribers), Vodacom (approximately 30.1 million subscribers), Cell C (approximately 22 million subscribers) and 8ta, a subsidiary of Telkom (approximately 2.3 million subscribers) (Businesstech, 2016; South Africa Info, 2016).

In 2015, South Africa had a total of 87.7 million mobile connections and a SIM penetration of $133 \%$. This implies that South Africans own more than one cellular phone (Fripp, 2017; Businesstech, 2016). The forecast for the South African market in 2020 is that it will be worth USD 3116.7 million, with an increase of $20.4 \%$ in sales between 2015 and 2020. The largest market share growth is predicted for Cell $\mathrm{C}$ with a potential annual 
growth in sales of $5 \%$, based on the possibility of a merger between Cell C and Telkom's 8ta. This merger is proposed to provide strong competition to the current market leaders in the South African market, namely Vodacom and MTN (South Africa Info, 2016). In 2020 , it is expected that the South African mobile phone market will represent a volume of approximately 28652 million units, indicating a growth of $32.6 \%$ from 2015 (MarketLine, 2016).

It is evident that the South African cell phone market is characterised by fierce competition, and merely satisfying customers is not enough for a cell phone network service provider to survive and prosper. The study therefore explores whether perceived employee service delivery skills and value can lead to satisfied customers being delighted, and whether this state will ultimately influence the behavioural intention of customers of cell phone network service providers.

\section{Theories grounding the study}

The study draws on the principles of the Theory of Reasoned Action (TRA) and the Relationship Marketing theory with respect to the constructs investigated and the proposed relationships between the constructs. Hoogstraten et al. (1985) state that the TRA, which was proposed by Ajzen and Fishbein in 1980, suggests that changes in consumer behaviour are primarily caused by two factors. The first factor is changes in "beliefs about the consequences of performing or non-performing the target behaviour", and the second factor relates to "the beliefs a person has about whether other people will approve or disapprove of his or her performing the target behaviour" (Hoogstraten et al., 1985). Newton et al. (2014) concur by stating that the fundamental principle of the TRA relates to the fact that a person will endorse actions that will secure desired results and which are supported by others. Thrasher et al. (2011) conclude that one factor is of a personal nature and the other reflects social influence. The TRA ultimately proposes a model that predicts consumer intention which is grounded in the attitudinal and normative beliefs of a person (Southey, 2011). Paul, Modi and Patel (2016) validate the relevance of the TRA in social sciences by stating that the key foundation of TRA is the intention of an individual to engage in given behaviour. They further continue to validate the relevance of TRA by stating that this theory has outstanding predictableness and has been very much relevant to forecast the behavioural intentions and behaviours of individuals in the fields of marketing management and consumer behaviour.

In terms of the Relationship Marketing theory, Knox and Gruar (2007) state that since the new millennium began, relationship marketing has played a growing role in the management of customers to build long-term relationships. They argue that relationship marketing offers a "reformist agenda" for the management of customers as it highlights customer collaboration in the establishment and management of the relationship-building process "beyond the immediacy of market transactions". Relationship Marketing theory departs from a customer orientation perspective with the primary advantage being the 
retention of the customer, increased loyalty, a reduction in marketing costs, and increased profits (Stavros and Westberg, 2009; Christopher et al., 2002; Berry and Parasuraman, 1991). Therefore, the theory of Relationship Marketing encompasses an all-inclusive approach towards marketing, aimed at managing existing customer relationships to secure customer loyalty as a behavioural outcome (Chang et al., 2015).

As highlighted earlier, the authors draw on the principles of these theories to hypothesise the relationships between the constructs of the study, in respect of South African cell phone network service providers, to determine the extent to which customer delight with the network is influenced by their perceptions of employee service delivery skills and of the value of the network's offerings. In turn, the influence of the extent of their delight on future behavioural intention is determined. No previous study in the context of South African cell phone network service providers has applied the Theory of Reasoned Action to understand the factors that influence customer satisfaction and customer delight, thereby guiding future behavioural intention.

\section{Perceived employee service delivery skills}

Studies in services marketing by Cronin and Taylor (1994) and Babakus et al. (2004), amongst others, have all indicated that employee satisfaction is critical for the delivery of superior levels of service quality to customers. Gratified employees are much more willing to deliver these levels of service quality over the long run (RamseookMunhurrun et al., 2009). Roberts-Lombard (2013) opines furthermore that employees of a service business should become more customer-centric through the delivery of high quality, market-driven service to customers, and such a customer-centric focus would then become the foundation for securing the establishment of a long-term relationship with customers. Fatima and Razzaque (2014) also argue that customers are more likely to have a positive service experience if they experience positive service delivery from the employees of a service business. Therefore, if customers believe the quality of service delivery provided by employees is below their expectations, they will easily move their spending power to a competitor (Dinh and Pickler, 2012). In this research study, the measurement of customer perceptions of employee service delivery skills in the context of cell phone network service provision focused on employees' ability to communicate with customers, to provide customers with personalised attention, to care for customers, and to understand their needs.

\section{Perceived value}

The concept of value can be described as the exchange between what a consumer receives from a product or service, and what the consumer pays for it (Manoj and Sahadev, 2011). In addition, value is created with the customer and not for the customer (Baena-Arroyo et al., 2016). Holbrook (1999) argues that the concept of value is relative and based on choices made on the basis of comparison or personal and situational circumstances. These choices are also typical of the experience that a person has through interaction with a product or service. Stronger arguments have been made for 
the conceptualisation of perceived value as a multidimensional construct (Andrews, Drennan and Russell-Bennett, 2012). Perceived value is often considered unidimensional or multidimensional (Chang and Dibb, 2012; Raza et al., 2012; Boksberger and Melsen, 2011; Doyle, 2011; Cheng et al., 2009; Lee et al., 2007; Chen and Hu, 2010; Sheth et al., 1991), but Coutelle-Brillet et al. (2014) state that perceived value is two-dimensional. The first dimension is either extrinsic (the product or service forms the basis on which value is defined), or intrinsic (the actual experience of consumption defines the value perception). In terms of the second dimension, the determination of the value received is individually defined through either the individual's own perceptions or the influence of others such as family, friends, colleagues or society in general. In this research study, both extrinsic and intrinsic dimensions of perceived value were considered (Nyadzayo, 2010).

\section{Customer satisfaction and customer delight}

Customer satisfaction has been well researched in the marketing literature (AbdulMuhmin, 2005; Burnham et al., 2003; Razzaque and Boon, 2003) as the foundation for long-term relationship building. In a B2C relationship, businesses such as service providers should ensure high levels of customer satisfaction during each business transaction (Theron, Terblanche and Boshoff, 2012). Wu (2014) defines customer satisfaction as "a person's subjective evaluation of his or her situation resulting in a positive emotional response". Customer satisfaction relates to the way a product or service can meet or surpass the expectations of customers. Calvo-Porral and LévyMangin (2015) state that satisfaction has developed as a key element in customer decision making to continue the relationship with the business. Therefore, if an organisation can provide value to its customer base that is defined by their needs, it will be more successful in meeting or surpassing customer expectations (Yeh, 2016; Raza et al., 2012). Exceeding customer expectations through improved service delivery, as a value adding tool, can ultimately lead to customer delight (Correia et al., 2014; BowdenEverson et. al. 2013; Denning, 2012; Matzler et al., 1996). Therefore, customer satisfaction as a key element in the relationship management process positively influences behavioural intentions when customer expectations are met or exceeded (Biggemann, 2010). Calvo-Porral and Lévy-Mangin (2016) concur by stating that in competitive market environments, securing increased levels of customer satisfaction can provide the organisation with a differential advantage from competitors and strengthen customer commitment. There is consensus amongst most researchers that customer satisfaction and customer delight are different from each other (Torres and Kline, 2013). Customer satisfaction is considered as a pre-condition for customer delight to occur (Bowden-Everson et al., 2013)

Torres and Kline (2013) define customer delight as "going beyond satisfaction to delivering what can be best described as a pleasurable experience for the client". Liu and Keh (2015) assert that customer delight is grounded in emotions, needs and the disconfirmation theories. According to Berman (2005), customer delight is often coupled with emotions such as surprise and joy. Customers are mostly satisfied when their needs are met or exceeded, but are delighted when they experience a combination of joy and 
surprise (Berman, 2005). Schneider and Bowen (1999) propose that customer delight stems from the basic needs of consumers and relates to their states of emotion. The disconfirmation theory holds further that when customer expectations are exceeded, it gives rise to customer delight (Loureiro et al., 2014; Oliver, 1989). Finally, Torres et al. (2014) argue that delighting customers can result in long-term profitability for the business. In this research study, customer satisfaction and delight were viewed from a disconfirmation paradigm perspective, and the construct was accordingly measured, determining the extent to which customer expectations were met or exceeded.

\section{Behavioural intention}

Behavioural intention refers to the likelihood that an individual will take part in a particular behaviour. It also represents the level of effort that an individual is willing to make to secure a specific behaviour (Maduku, 2015; Fishbein and Middlestadt, 2012; Ajzen, 1991). High levels of customer satisfaction and a positive customer experience lead directly to positive behavioural intention towards the service supplier ( $\mathrm{Yu}$ et al., 2014). Lam, Lau and Cheung (2016), Wu (2014) and Meng et al. (2011) argue that empirical evidence has proven that customer satisfaction has a significant influence on behavioural intentions in a service environment. Mohsan et al. (2011) concur and state that customer satisfaction and behavioural intention are strongly related, and that discontent strengthens a customer's negative behavioural intention such as to churn or spread negative word of mouth. Dölarslan (2014) argues that from a services marketing perspective in the emerging markets, research on the relationships among employee skills, perceived value (both drivers of customer satisfaction), customer satisfaction and behavioural intention requires greater attention.

\section{Theoretical model development}

The interrelationship between perceived employee service delivery skills and customer satisfaction/delight experiences

Studies by Cronin and Taylor (1994) and Babakus et al. (2004) have indicated that there is a direct relationship between the level of service quality delivered by employees and customer satisfaction. It has also been found that employees who are committed to high levels of service delivery to customers can enhance the overall customer satisfaction of these customers (Ramseook-Munhurrun et al., 2009). Fatima and Razzaque (2014) concur with this finding by stating that customers will rate a service experience more highly if the employees of the organisation have higher levels of engagement with the customer. In addition, several studies conducted by Bitner et al. (1990), Tsai (2001) and Tsai and Huang (2002), amongst others, have established that the delivery of a friendly, understanding service to customers has a positive link with customer satisfaction (Lin and Lin, 2011). 
Based upon these findings, the following hypothesis can be formulated for the study:

$\mathrm{H}_{1}$ : Perceived employee service delivery skills influence customer satisfaction/delight experiences of cell phone network service provider customers.

The interrelationship between perceived value and customer satisfaction/delight experiences

The research of Dedeoğlu et al. (2016), Lee et al. (2016), Lam et al. (2016) and Vera (2015) propounds that there is a direct relationship between the value that customers perceive they derive from a service offering, and their levels of customer satisfaction. It is furthermore claimed that, from a marketing perspective, the importance of perceived value is that it creates customer satisfaction (Makanyezaa et al., 2016). Loureiro et al. (2014) concur by stating that perceived value is directly linked to customer satisfaction.

Based upon these findings, the following hypothesis can be formulated for the study:

$\mathrm{H}_{2}$ : Perceived value influences customer satisfaction/delight experiences of cell phone network service provider customers.

The interrelationship between customer satisfaction/delight experiences and behavioural intention

Alexander (2012) argues that when a customer purchases from a business, the customer has expectations that his/her needs will be met, and this will in turn influence the behavioural intention of the customer. Finn (2012) states that for decades customer satisfaction has been the central focus of numerous literature studies involving customer expectations, and more specifically, the disconfirmation paradigm. These research studies provide a strong argument that customer satisfaction influences behavioural intentions related to repeat purchases. Jenefa and Kaliyamoorthy (2014), Amin and Nasharuddin (2013), Gounaris and Boukis (2013) and Ibrahim and Najjar (2007) indicate that customer satisfaction leads to positive behavioural intentions.

Based upon these findings, the following hypothesis can be formulated for the study:

$\mathrm{H}_{3}$ : Customer satisfaction/delight experiences influence the behavioural intention of cell phone network service provider customers.

Figure 1 depicts the proposed theoretical model for this study, illustrating the four constructs of the study as well as the hypothesised relationships between these constructs. 
Figure 1. Proposed theoretical model

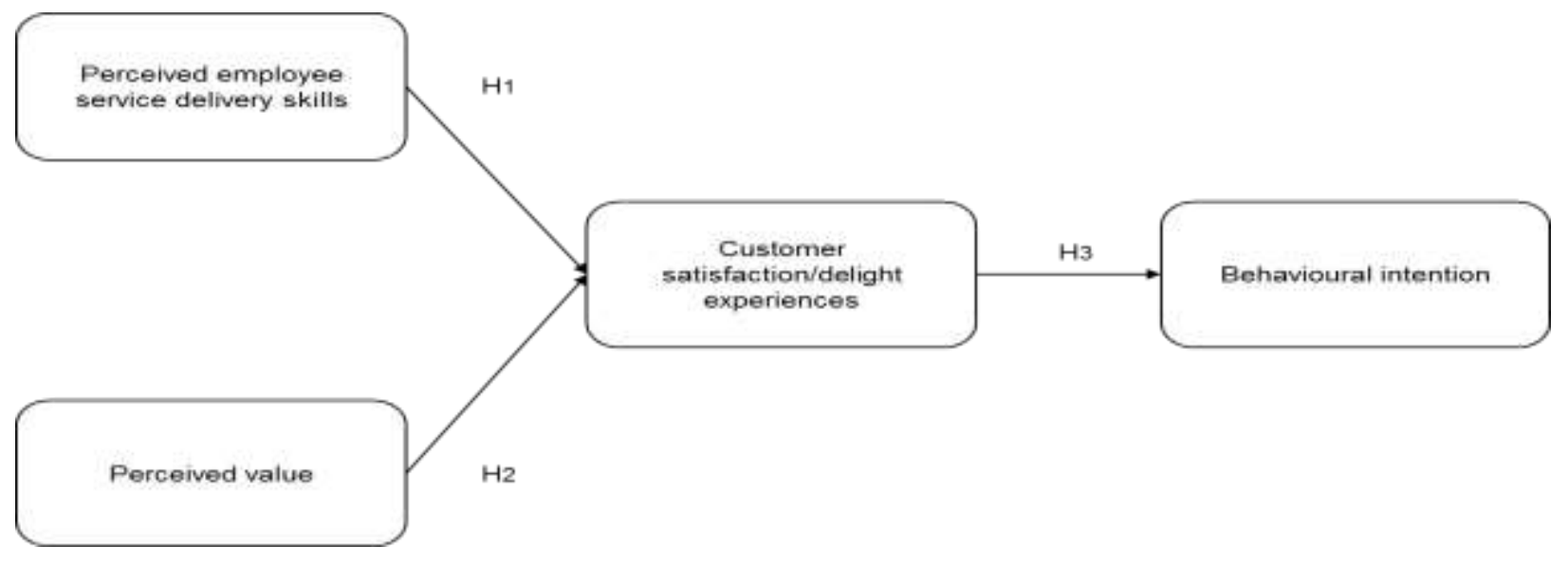

Source: Researchers' own construct

\section{Methodology}

Research context and sample

A descripto-explanatory research design was followed and data was collected from cell phone network service provider customers who resided in the South African province of Gauteng and who owned a cell phone, had a choice of cell phone network service provider to use, and considered themselves satisfied customers of these networks at the time the survey was conducted. These customers represented the sampling units and elements of the study.

The study focused specifically on customers who considered themselves at least satisfied with the cell phone network service provider as satisfaction is seen as a precondition for customer delight (Bowden-Everson et al., 2013). The reason for doing so, was to uncover the extent to which these customers are delighted with the cell phone network service provider. Screening questions and quotas were used to ensure the sample meet the set requirements to take part in the study. As a result, respondents from all over the province, across all cell phone network service providers, who had a choice in the network they are using and whom considered themselves satisfied customers of these networks took part in the study.

A total of thirty fieldworkers residing all over the province were employed to collect data from respondents. Fieldworkers were required to identify individuals in their own network of friends, family and colleagues that meet the above-mentioned criteria. The fieldworkers furthermore had to fill age and gender quotas purposefully to ensure the target population was adequately presented. The sample was thus selected using nonprobability sampling filling pre-determined quotas purposefully. Respondents were required to complete self-administered paper-based questionnaires and return the completed questionnaires to the fieldworkers. Data was collected over a two-week period. A total of 593 useable questionnaires were collected for analysis. 
Self-administered questionnaires were used to collect the data. The questionnaire commenced with a preamble and three screening questions to ensure that prospective respondents were indeed part of the target population of the study. The questionnaire included sections inquiring about the demographic profile and cell phone network patronage habits of respondents. To measure the constructs of the study, seven-point unlabelled Likert-type scales were used to measure the level of agreement with respect to items measuring perceived employee service delivery skills (PESDS), perceived value (PV) and behavioural intention (BI). The construct customer satisfaction/delight experiences (CSD) was measured using a semantic differential scale with seven response categories. The scale measuring PESDS was adapted from Van Vuuren (2011), the scale measuring PV was adapted from Nyadzayo (2010), the scale measuring CSD was developed from Berman (2005), and the scale measuring BI was adapted from Dagger and Sweeney (2007). Table 1 provides insight into the items used to measure each of the constructs.

Table 1. Constructs and items

\begin{tabular}{|c|}
\hline $\begin{array}{l}\text { Perceived employee service delivery skills (PESDS) } \\
X_{1} \text { Cell phone network service provider employees listen when I communicate to them }\end{array}$ \\
\hline $\mathrm{X}_{2}$ Cell phone network service provider employees provide me with personalised attention \\
\hline $\mathrm{X}_{3}$ Cell phone network service provider employees genuinely care about me as a customer \\
\hline $\mathrm{X}_{4}$ Cell phone network service provider employees understand my needs \\
\hline Perceived value (PV) \\
\hline $\mathrm{X}_{5}$ My cell phone network service provider offers me value for money \\
\hline $\mathrm{X}_{6} \mathrm{I}$ consider the rates of my cell phone network service provider as reasonable \\
\hline $\begin{array}{l}\mathrm{X}_{7} \text { Doing business with my cell phone network service provider is a right decision when price and other } \\
\text { costs are considered }\end{array}$ \\
\hline $\begin{array}{l}\text { X Doing business with my cell phone network service provider is a right decision when the overall } \\
\text { quality of service delivery is considered }\end{array}$ \\
\hline $\mathrm{X}_{9}$ Compared to the quality of cellular service reception that I get, I pay a reasonable price \\
\hline Customer satisfaction/delight experiences (CSD) \\
\hline $\begin{array}{l}\mathrm{X}_{10} \text { The service of the cell phone network service provider meets or slightly/drastically exceeds my } \\
\text { expectations }\end{array}$ \\
\hline $\begin{array}{l}\mathrm{X}_{11} \text { I believe I received reasonable/extremely high value from the services offered by the cell phone } \\
\text { network service provider }\end{array}$ \\
\hline $\mathrm{X}_{12}$ The employees of the cell phone network service provider are competent/highly competent \\
\hline $\begin{array}{l}\mathrm{X}_{13} \text { The services offered by the cell phone network service provider are memorable/especially } \\
\text { memorable }\end{array}$ \\
\hline $\mathrm{X}_{14}$ The services offered by the cell phone network service provider are relatively/particularly unique \\
\hline $\begin{array}{l}X_{15} \text { The cell phone network service provider provides basic/the highest level of post-purchase customer } \\
\text { support }\end{array}$ \\
\hline $\mathrm{X}_{16}$ The cell phone network service provider offers basic/extensive service recovery \\
\hline Behavioural intention (BI) \\
\hline $\begin{array}{l}X_{17} \text { If I had to choose a cell phone network service provider all over again, I would choose my current } \\
\text { cell phone network service provider }\end{array}$ \\
\hline $\mathrm{X}_{18}$ I would highly recommend my cell phone network service provider to other people \\
\hline $\mathrm{X}_{19} \mathrm{I}$ intend to continue using my cell phone network service provider in the future \\
\hline
\end{tabular}

After the data was edited and cleaned it was entered into SPSS 23.0. Using SPSS 23.0, frequencies and descriptive statistics were calculated to gain insight into the 
demographic profile of respondents, their cell phone network service provider patronage habits, and the 19 items measuring the four constructs of the study. An exploratory factor analysis using the Maximum likelihood method for extraction and Promax for rotation was used to uncover the interrelationships between the items measuring the study's constructs. The measurement model and structural model were assessed using AMOS 23.0. Prior to assessing the structural model, assumptions (underlying covariance-based structural equation modelling using AMOS 23.0) related to linearity and multicollinearity were addressed.

\section{Empirical findings}

\section{Profile of respondents}

The average respondent is 37 years of age and, since gender quotas were filled, the sample is almost equally split between male and female respondents. Most respondents $(37.9 \%)$ have a university degree followed by those who have completed high school $(28.5 \%)$. Half of the respondents are employed full-time by an organisation $(49.4 \%)$, followed by those who are self-employed (15.5\%) and those who are students (14.3\%). Most respondents are Vodacom customers (43.2\%) followed by MTN (33.4\%) and Cell C (15.3\%) customers respectively. On average, respondents have been with their cell phone network service providers for nearly eight years. A total of $56.8 \%$ of respondents are contract customers and the remaining $43.2 \%$ of respondents are prepaid customers. Respondents spend on average R521 per month on their cell phone contract, accounts, prepaid vouchers, sms bundles and other expenses.

\section{Exploratory factor analysis}

The Kaiser-Meyer-Olkin Measure of Sampling Adequacy of 0.934 exceeds the cutoff point of 0.7 , with a significance level of $p<0.0005$ for the Bartlett's Test of Sphericity signifying the factorability of the correlation matrix (Pallant, 2013). The communalities for all items are above the cut-off point of 0.3 , ranging between 0.445 and 0.899 . Four factors with an Eigenvalue $\geq 1$ have been extracted, explaining $71.33 \%$ of the variance. This is above the recommended minimum of $60 \%$. The reproduced correlation matrix indicates only $2 \%$ non-redundant residuals. This is below the permissible maximum of $5 \%$ nonredundant residuals. The pattern matrix indicates that all items load above 0.5 on a single factor, with loadings ranging between 0.583 and 0.998 , while the average loadings per factor all exceed 0.7 . Convergent validity of the scale measuring the constructs of the study can therefore be confirmed. Discriminant validity of these scales can also be confirmed since none of the items cross load at above 0.2 , and the factor correlation matrix shows that pairs of factors share less than $49 \%$ of the variance.

\section{Measurement model assessment}

With the aid of AMOS 23.0, a confirmatory factor analysis was performed on the 19item four-construct model to assess the psychometric properties of the model. The model was specified and adjusted based upon modification indices calculated to improve the 
model fit in this instance, the normed chi square ( $\left.X^{2} / d f\right)$ (Jöreskog and Sörbom, 1993). The adjustments made to the model can be supported by the literature since covariances were only included between errors terms of items measuring the same construct (Wang, Jackson, Gaskin and Wang, 2014). Table 2 presents the results for the measurement model. It is evident that all goodness-of-fit measures fall within the limits as prescribed by Hair et al. (2014). The normed chi square (X $\left.{ }^{2} / d f\right)$, NFI, RFI, IFI, TLI and CFI are all above the cut-off of 0.9 , and the RMSEA is below a value of 0.08 . The goodness-of-fit measures in combination give evidence of good model fit (Hair et al., 2014).

Table 2. Measures for goodness-of-fit (measurement model)

\begin{tabular}{|c|c|c|c|c|c|c|c|c|c|}
\hline CMIN & DF & P & CMIN/DF & NFI & RFI & IFI & TLI & CFI & RMSEA \\
\hline 379.26 & 139 & 0.00 & 2.73 & 0.96 & 0.95 & 0.98 & 0.97 & 0.96 & 0.054 \\
\hline
\end{tabular}

Table 3 provides insight into the factor loading, variance explained, and the means and standard deviations of the 19 items used to measure the four constructs of the study. The factor loading for each item is above 0.5 , and the factor loadings for all 19 items vary between 0.661 and 0.930 . Therefore none of the items were removed. The explained variance of each item is above 0.3 , ranging from 0.437 to 0.864 . When considering the descriptive statistics for the items, it is evident that the means vary between 3.54 and 4.97, with standard deviations of between 1.439 and 1.777 . This is indicative of regularity between the items measuring the constructs of the study.

Table 3. Factor loadings, variance explained, means (M) and standard deviations (SD)

\begin{tabular}{|c|c|c|c|c|c|}
\hline Construct & Item & $\begin{array}{c}\text { Factor } \\
\text { loading }\end{array}$ & $\begin{array}{c}\text { Variance } \\
\text { explained }\end{array}$ & $\mathbf{M}$ & SD \\
\hline \multirow{4}{*}{ PESDS } & $\mathrm{X}_{1}$ & 0.779 & 0.606 & 4.65 & 1.498 \\
\cline { 2 - 6 } & $\mathrm{X}_{2}$ & 0.871 & 0.759 & 4.34 & 1.608 \\
\cline { 2 - 6 } & $\mathrm{X}_{3}$ & 0.909 & 0.827 & 4.25 & 1.592 \\
\cline { 2 - 6 } & $\mathrm{X}_{4}$ & 0.867 & 0.752 & 4.38 & 1.510 \\
\cline { 2 - 6 } & $\mathrm{X}_{5}$ & 0.876 & 0.768 & 4.46 & 1.632 \\
\cline { 2 - 6 } & $\mathrm{X}_{6}$ & 0.786 & 0.618 & 4.31 & 1.668 \\
\cline { 2 - 6 } & $\mathrm{X}_{7}$ & 0.796 & 0.633 & 4.57 & 1.550 \\
\cline { 2 - 6 } & $\mathrm{X}_{8}$ & 0.894 & 0.799 & 4.64 & 1.439 \\
\hline \multirow{4}{*}{ PV } & $\mathrm{X}_{9}$ & 0.803 & 0.644 & 4.66 & 1.531 \\
\cline { 2 - 6 } & $\mathrm{X}_{10}$ & 0.765 & 0.586 & 3.85 & 1.533 \\
\cline { 2 - 6 } & $\mathrm{X}_{11}$ & 0.811 & 0.657 & 4.00 & 1.518 \\
\cline { 2 - 6 } & $\mathrm{X}_{12}$ & 0.661 & 0.437 & 4.09 & 1.944 \\
\cline { 2 - 6 } & $\mathrm{X}_{13}$ & 0.844 & 0.712 & 3.54 & 1.634 \\
\cline { 2 - 6 } & $\mathrm{X}_{14}$ & 0.861 & 0.741 & 3.69 & 1.674 \\
\cline { 2 - 6 } & $\mathrm{X}_{15}$ & 0.793 & 0.629 & 3.94 & 1.556 \\
\hline \multirow{4}{*}{ BI } & $\mathrm{X}_{16}$ & 0.806 & 0.649 & 3.97 & 1.609 \\
\cline { 2 - 6 } & $\mathrm{X}_{17}$ & 0.930 & 0.864 & 4.77 & 1.751 \\
\cline { 2 - 6 } & $\mathrm{X}_{18}$ & 0.908 & 0.824 & 4.56 & 1.777 \\
\hline
\end{tabular}


Convergent validity, discriminant validity and composite trait reliability

Convergent validity was assessed by determining whether the average variance extracted (AVE) for each construct is above 0.5 (Hair et al., 2014). It is evident from Table 4 that the AVEs for all four constructs exceed 0.5 and range between 0.630 and 0.824 , thus confirming convergent validity. Discriminant validity was assessed by determining whether the AVEs of the constructs exceed the corresponding inter-construct correlations. It is also evident from Table 4 that this is indeed the case as they vary between 0.282 and 0.529 , well below the lowest variance extracted (63.0\%). Discriminant validity can therefore be confirmed. Finally, composite trait reliability was assessed by determining whether the cut-off value of 0.7 was exceeded. It is evident from Table 4 that the composite trait reliabilities exceed the cut-off value of 0.7 , ranging between 0.811 and 0.933. Composite trait reliability could therefore be confirmed.

Table 4. Average variance extracted, squared interconstruct correlations and composite trait reliability

\begin{tabular}{|c|c|c|c|c|}
\hline Variable & PESDS & PV & CSD & BI \\
\hline PESDS & $\mathbf{0 . 6 8 3}^{\boldsymbol{*}}$ & & & \\
\hline PV & 0.529 & $\mathbf{0 . 6 9 3}^{\boldsymbol{*}}$ & & \\
\hline CSD & 0.358 & 0.311 & $\mathbf{0 . 6 3 0}^{\boldsymbol{*}}$ & \\
\hline BI & 0.354 & 0.411 & 0.282 & $\mathbf{0 . 8 2 4}^{\boldsymbol{*}}$ \\
\hline Composite trait reliability & 0.811 & 0.918 & 0.922 & 0.933 \\
\hline
\end{tabular}

* AVE reflected diagonally and squared correlations below AVE

Linearity and multicollinearity

The relationships between pairs of constructs linked to one another in the structural model (PESDS and CSD, PV and CSD, as well as CSD and BI) were found to be linear as the $F$-values for the respective linear models all exceed the F-values of other models considered. Multicollinearity between constructs on the same level (PESDS and PV) influencing another variable (CSD) was not an issue as the variance inflation factor was less than 3 (Pallant, 2013).

\section{Structural model assessment}

Once the psychometric properties of the model had been assessed and underlying assumptions checked, it was necessary to assess the structural properties of the model. As with the measurement model, the following goodness-of-fit measures were assessed, namely the chi-square, the normed chi-square $\left(X^{2} / d f\right)$, the NFI, RFI, IFI, TLI, CFI and the RMSEA. Table 5 indicates that all goodness-of-fit measures fall within the limits as prescribed by Hair et al. (2014), except for the normed chi-square $\left(X^{2} / d f\right)$, which slightly exceeds the value of 3 . The NFI, RFI, IFI, TLI and CFI are all above the cut-off of 0.9 and the RMSEA is below a value of 0.08. It is evident from Hair et al. (2014) that although a goodness-of-fit measure might exceed the cut-off, as is the case with normed chi-square 
$\left(X^{2} / d f\right)$ in the structural model, considering the goodness-of-fit measures in combination, adequate model fit is evident.

Table 5. Measures for goodness-of-fit (structural model)

\begin{tabular}{|c|c|c|c|c|c|c|c|c|c|}
\hline CMIN & DF & P & CMIN/DF & NFI & RFI & IFI & TLI & CFI & RMSEA \\
\hline 457.211 & 135 & 0.00 & 3.387 & 0.95 & 0.94 & 0.97 & 0.96 & 0.97 & 0.06 \\
\hline
\end{tabular}

Table 6 provides insight into the findings with respect to the hypotheses formulated for the study. All three hypotheses can be supported. Based upon these findings, nomological validity is also evident.

Table 6. Hypothesis testing

\begin{tabular}{|c|c|c|c|c|c|}
\hline Hypothesis & Variable & Variable & $\boldsymbol{\beta}$ & Sig. & Finding \\
\hline $\mathrm{H}_{1}$ & PESDS & $\mathrm{CSD}$ & 0.39 & 0.00 & Supported \\
\hline $\mathrm{H}_{2}$ & $\mathrm{PV}$ & $\mathrm{CSD}$ & 0.32 & 0.00 & Supported \\
\hline $\mathrm{H}_{3}$ & $\mathrm{CSD}$ & $\mathrm{BI}$ & 0.57 & 0.00 & Supported \\
\hline
\end{tabular}

\section{Discussion}

The study makes both a theoretical and a practical contribution. From a theoretical perspective, the results confirm that the measurement scales used to measure the customer satisfaction/delight experiences construct, its antecedents and outcome are reliable and valid. The model as proposed has been verified, confirming the B2C relationships between customer satisfaction/delight experiences, its antecedents and behavioural intention within an emerging market context.

From a managerial perspective, the study contributes in potentially assisting cell phone network service providers to understand how perceived employee service delivery skills and value can foster customer delight, ultimately leading to positive behavioural intentions from customers. This outcome will, however, depend on whether the customer perceives both the employee service delivery skills and the value received as positive. However, as noted by Berman (2005), it remains important to understand that "consumers' expectation sets continuously change due to competition, the economy, and their experiences and that different market segments may have different expectation sets". It therefore becomes imperative for cell phone network service providers to remain innovative in terms of their business processes to secure the delivery of superior value to customers. Innovation can be secured through an analysis of the value chain. The value chain will emphasise the cellular network service provider's capabilities (such as the level of employee service delivery skills), proficiencies (ability to secure customer satisfaction/delight experiences) and resource competencies.

From a theoretical perspective, the study makes two contributions. Firstly, it establishes that the customer satisfaction/delight experiences of customers in relation to their cell phone network service providers in an emerging market do lead to the positive behavioural intentions of these customers. It can therefore be argued that the different 
constructs claimed in theory to drive behavioural intention do have an influence on the behavioural intention of customers in an emerging market context, as hypothesised in this study. It should be noted that customer delight is a new research focus area, and limited studies have focused on the influence of customer satisfaction/delight experiences on behavioural intention. This finding is important as it illustrates what constitutes customer satisfaction/delight experiences, and how this influences behavioural intention. The two dimensions of customer satisfaction/delight could be used by future researchers to study the influences of customer satisfaction/delight on various domains, such as customer retention or customer loyalty. Therefore, the study contributes to customer delight literature by proposing useful measurement dimensions.

Secondly, the study provides an improved understanding of the influence of customer satisfaction/delight constructs on behavioural intention from the perspective of an emerging economy and a competitive industry such as the cellular phone industry. The research study proposes a model that clarifies how perceived employee service delivery skills and perceived value have a direct influence on customer satisfaction/delight, with the latter influencing behavioural intention. Therefore, the positive influence of customer delight on the behaviour of consumers can provide an organisation with a competitive advantage (Arnold et al., 2005).

\section{Managerial implications}

Considering the implications of the study, it can be said that cell phone network service providers in an emerging market should focus on the creation of experiences that lead to customer delight, as this would result in customers having positive behavioural intentions towards the provider. Cell phone network service providers should foster a service culture built and based on exceeding customer expectations. There should be a continuous focus on providing customers with a high value of service delivery through competent, friendly and engaging employees. This should secure a memorable customer experience which is inclusive of professional post-purchase customer support service delivery. Customers want to experience an offering that satisfies their needs and that also provide customer satisfaction and value (Crotts and Magnini, 2011). Considering this, it becomes imperative for cell phone network service providers to provide their customers with service delivery that not only meets their expectations, but exceeds them.

Secondly, the facilitation of service delivery requires an individual approach, contextualised by the specific service requirement of the customer, and supported through the development of a one-on-one engagement approach to secure positive customer behaviour in the form of delight. This will require cell phone network service providers to create a customer experience through delightful service interaction whereby the customer engages positively with the cell phone network service provider before, during and after each service interaction. This can be secured if service employees provide a personalised service delivery experience to customers, secure positive and focused communication before, during and after the formal service engagement, and provide a caring attitude for the service needs of customers. 
Thirdly, customer delight can be brought about through a greater focus on improving employee service delivery skills through the training and development of employees. Such training and development can encompass aspects such as focusing on improved communication and interaction with customers, acknowledging customers when they contact the cell phone network service provider, offering language training courses, improving product knowledge, and mastering conflict resolution skills. Secondly, there should also be a greater focus on what customers of cell phone network service providers perceive as value in a B2C relationship. Perceived value will depend on factors such as rates, prices and costs associated with doing business with the cell phone network service provider, as well as the service quality on offer, to name but a few.

Finally, cellular network providers should make a concerted effort to have a comprehensive knowledge and understanding of the different needs of their segmented customer base. An empathetic approach towards customers is a critical element in creating a positive customer experience. Customer satisfaction and delight are enhanced when the service provider is committed to its customers, is truly passionate about its customers, and provides a service level of high quality, irrespective of the time of day or the day of the week. A speedy response to customer enquiries, queries and proposals should be provided, which can add functional value to a customer's perception of satisfaction or delight. Finally, it is critical to establish and nurture a true friendship with customers. Therefore, to develop strong customer relationships which could be channelled into positive customer satisfaction or delight experiences, a cellular network provider should be open to suggestions, criticisms and comments. Honesty and openness are key ingredients in cultivating and managing positive relationships with customers.

\section{Conclusions}

The purpose of this study was to investigate the extent to which the delight experienced by customers of cell phone network service providers is influenced by their perceptions of the network's employee service delivery skills and the value that the customers experience in the network's offerings. In turn, the influence of their degree of delight on future behavioural intention was established. The study concluded that the satisfaction/delight experiences of cell phone network service provider customers do lead to positive behavioural intention. However, this depends on whether customers perceive the employee service delivery skills provided and the value received as positive. In conclusion, the results of this study contribute to an understanding of customer satisfaction/delight experiences with cell phone network service providers in an emerging market context. The study further provides direction to cell phone network service providers on the building of relationships with their customers over the long term through a greater emphasis on creating customer delight. From an emerging economy perspective, it is recommended that these customers are provided with service experiences that could lead to a feeling of customer delight, resulting in positive behavioural intentions towards the cell phone network service provider. The commitment of customers in emerging economies are driven by positive experiences, and can be supported by a service culture built and based on exceeding customer expectations. 
Therefore, cell phone network service provider operating in emerging economies should understand the desire of customers to continuously be provided with value through high quality service delivery, supported by skilled, engaging and spontaneous employees. Through such an approach, a positive behavioural intention amongst customers will be secured and customer commitment strengthened.

The study is limited by the fact that only two antecedents, namely the service experience and perceived value perceptions of customers, are considered in a single service setting. However, the study does provide concise insights into these two antecedents of customer satisfaction/delight experiences within the South African cell phone network service provider context, and into the degree to which customer satisfaction/delight experiences are influenced by their antecedents (perceived employee service delivery skills and perceived value) and determine their outcome (behavioural intention). An understanding of this should assist cell phone network service providers in South Africa to prioritise the fostering of customer satisfaction/delight experiences, which should benefit both themselves and their customers.

\section{References}

Abdul-Muhmin, A.G. (2005), "Instrumental and interpersonal determinants of relationship satisfaction and commitment in industrial markets". Journal of Business Research, Vol. 58 No 5, pp. 619-628.

Ajzen, I. (1991), "The theory of planned behaviour", Organizational Behavior and Human Decision Processes, Vol. 50 No. 2, pp. 179-211.

Ajzen, I. and Fishbein, M. (1980), Understanding attitudes and predicting social behaviour, Prentice-Hall, Engelwood Cliffs, NJ.

Alexander, M.W. (2012), "Delight the Customer: A Predictive Model for Repeat Purchase Behavior", Journal of Relationship Marketing, Vol. 11, pp. 116-123.

Amin, M. and Nasharuddin, S.Z. (2013), "Hospital service quality and its effects on patient satisfaction and behavioural intention", Clinical Governance: An International Journal, Vol. 18 No. 3, pp. 238-254.

Andrews, L., Drennan, J. and Russell-Bennett, J.D.R. (2012), "Linking perceived value of mobile marketing with the experiential consumption of mobile phones", European Journal of Marketing, Vol. 46, No 3/4, pp. 357 - 386.

Arnold, M.J., Reynolds, K.E., Ponder, N. and Lueg, J.E. (2005), "Customer delight in a retail context: investigating delightful and terrible shopping experiences", Journal of Business Research, Vol. 58 No. 8, pp. 1132-1145. 
Babakus, E., Bienstock, C.C. and Scotter, J.R.V. (2004), "Linking perceived quality and customer satisfaction to store traffic and revenue growth", Decision Science, Vol. 35 No. 4, pp. 713-737.

Baena-Arroyo, M.J., Gálvez-Ruiz, P., Sánchez-Oliver, A.J. and Bernal-García, A. (2016), "The relationship among service experience, perceived value and behavioural intentions of customers in a group fitness class", Revista de Psicología del Deporte, Vol. 25 No. 1, pp. 89-92.

Bendi, M. (2016), Telecommunications in South Africa - SA Cellular Industry. MBendi Information Services, pp. 1-4.

Berman, B. (2005), "How to delight your customers", California Management Review, Vol. 48 No. 1 , pp. $129-151$.

Berry, L.L. and Parasuraman, A. (1991), Marketing Services - Competing through Quality, Free Press, New York, NY.

Biggemann, S. (2010), "Chapter 3 Modeling the structure of business-to-business relationships" In Organizational Culture, Business-to-Business Relationships, and Interfirm Networks. Published online: 8 March 2015: 27-177.

Bitner, M.J., Booms, B.H. and Tetreault, M.S. (1990), "The service encounter: diagnosing favorable and unfavorable incidents", Journal of Marketing, Vol. 54 No. 1, pp. 7184.

Boksberger, P.E. and Melsen, L. (2011), "Perceived value: a critical examination of definitions, concepts and measures for the service industry", Journal of Services Marketing, Vol. 25 No. 3, pp. 229-240.

Bowden-Everson, J.L., Dagger, T.S. and Elliott, G. (2013), "Engaging Customers for Loyalty in the Restaurant Industry: The Role of Satisfaction, Trust, and Delight", Journal of Foodservice Business Research, Vol. 16, pp. 52-75.

Burnham, T.A., Frels, J.K. and Mahajan, V. (2003), "Consumer switching costs: A typology, antecedents, and consequences". Journal of the Academy of Marketing Sciences, Vol. 31 No 2, pp. 109-121.

Businesstech. (2016), 'SA mobile market share: Vodacom vs MTN vs Cell C vs Telkom' [Online] Available at:

http://businesstech.co.za/news/general/104249/samobilemarketsharevodacomvsm tnvscellcvstelkom/ (accessed 10 August 2016).

Calvo-Porral, C. and Lévy-Mangin, J-P. (2015). The influence of switching costs and satisfaction on loyalty towards smartphone service providers. Computers in Human Behaviour, Vol. 49, pp. 532-540. 
Calvo-Porral, C. and Lévy-Mangin, J-P. (2016). The influence of switching costs and satisfaction on loyalty towards smartphone service providers. International Journal of Mobile Communications, Vol. 14, No. 4, pp. 309-327.

Chang, C. and Dibb, S. (2012), "Reviewing and conceptualising customer-perceived value”, The Marketing Review, Vol. 12 No. 3, pp. 253-274.

Chang, H.H., Tsai, Y., Huang, S.C.G. and Tseng, Y.H. (2015), "Building long-term partnerships by certificate implementation: a social exchange theory perspective", Journal of Business and Industrial Marketing, Vol. 30 No. 7, pp. 867-879.

Chen, P.T. and Hu, H.H. (2010), "How determinant attributes of service quality influence customer perceived value: an empirical investigation of the Australian coffee outlet industry", International Journal of Contemporary Hospitality Management, Vol. 22 No. 4, pp. 535-551.

Cheng, J.M., Wang, E.S., Lin, J.Y. and Vivek, S.D. (2009), "Why do customers utilise the internet as a retailing platform?" A view from consumer perceived value", Asia Pacific Journal of Marketing, Vol. 21 No. 1, pp. 144-160.

Christopher, M., Payne, A. and Ballantyne, D. (2002), Relationship Marketing: Creating Stakeholder Value, Butterworth-Heinemann, Oxford.

Correia, S.M., Francisco, L., Miranda, J. and Breazeale, M. (2014), "Who needs delight?", Journal of Service Management, Vol. 25 Iss 1, pp. $101-124$.

Coutelle-Brillet, P., Riviere, A. and des Garets, V. (2014), "Perceived value of service innovation: a conceptual framework", Journal of Business and Industrial Marketing, Vol. 29 Iss. 2, pp. 164-172.

Cronin, J.J. and Taylor, S.A. (1994), "SERVPERF versus SERVQUAL: reconciling performance based and perceptions minus expectations measurement of service quality", Journal of Marketing, Vol. 58, pp. 125-31.

Crotts, J.C. and Magnini, V.P. (2011), "The customer delight construct - is surprise essential?", Annals of Tourism Research, Vol. 38, pp. 708-722.

Dagger, T.S. and Sweeney, J.S. (2007), "Service quality attribute weights: how do novice and longer-term customers construct service quality perceptions?", Journal of Service Research, Vol. 10 No. 1, pp. 22-42.

Denning, S. (2012), "From maximizing shareholder value to delighting the customer", Strategy and Leadership, Vol. 40 No 3, pp. 12 - 16. 
Dinh, V. and Pickler, L. (2012), "Examining Service Quality and Customer Satisfaction in the Retail Banking Sector in Vietnam", Journal of Relationship Marketing, Vol. 11 No 4, pp. 199-214.

Dedeoğlu, B.D., Balıkçıoğlu, S. and Küçükergin, K.G. (2016), "The Role of Tourists' Value Perceptions in Behavioral Intentions: The Moderating Effect of Gender", Journal of Travel and Tourism Marketing, Vol. 33 No 4, pp. 513-534.

Doyle, C. (2011), Oxford Dictionary of Marketing: The One-stop Guide for Marketers. Oxford University Press, New York, NY.

Fatima, J.K. and Razzaque, M.A. (2014),"Service quality and satisfaction in the banking sector", International Journal of Quality and Reliability Management, Vol. 31 No 4, pp. $367-379$.

Fishbein, M. and Middlestadt, S.E. (2012), "Using behavioural theory to transform consumers and their environments to prevent the spread of sexually transmitted infections", in Mick, D.G., Pettigrew, S., Pechmann, C.C. and Ozanne, J.L. (Eds.), Transformative Consumer Research for Personal and Collective Well-Being, Routledge, New York, NY, pp. 391-410.

Finn, A. (2012), "Customer Delight: Distinct Construct or Zone of Nonlinear Response to Customer Satisfaction?", Journal of Service Research, Vol. 15 No 1, pp. 99-110.

Fripp, C. (2017). "South Africa's mobile penetration is 133\%". [Online] Available at: http://www.htxt.co.za/2014/10/23/south-africas-mobile-penetration-is-133/ (accessed 10 August 2017).

Füller, J. and Matzler, K. (2008), "Customer delight and market segmentation: an application of the three-factor theory of customer satisfaction on life style groups", Tourism Management, Vol. 29, pp. 116-126.

Gounaris, S. and Boukis, A. (2013), "The role of employee job satisfaction in strengthening customer repurchase intentions", Journal of Services Marketing, Vol. 27 No. 4, pp. 322-333.

Hair, J.F., Black, W.C., Babin, B.J. and Anderson, R.E. (2014), Multivariate Data Analysis, 7th edition, Pearson, Harlow.

Holbrook, M.B. (1999), "Introduction to consumer value", in Holbrook, M.B. (Ed.), Consumer Value: A Framework for Analysis and Research, Routledge, New York, NY, pp. 1-28.

Hoogstraten, J.O.H., De Haan, W. and Ter Horst, G. (1985), 'Stimulating the demand for dental care, an application for Ajzen's and Fishbein's theory of reasoned action', European Journal of Social Psychology, 15, pp. 401-414. 
Ibrahim, H. and Najjar, F. (2007), "Assessing the effects of self-congruity, attitudes and customer satisfaction on customer behavioural intentions in retail environment", Marketing Intelligence and Planning, Vol. 26 No. 2, pp. 207-227.

Jenefa, L. and Kaliyamoorthy, R. (2014), "Behavioral Impact of Customer Satisfaction and Customer Retention in Textile", International Journal on Global Business Management and Research, Vol. 3 No. 1, pp. 51-63.

Jöreskog, K.G. and Sörbom, D. (1993), LISREL 8: Structural equation modelling with the SIMPLIS command language, Scientific Software International, Chicago.

Knox, S. and Gruar, C. (2007), "The Application of Stakeholder Theory to Relationship Marketing Strategy Development in a Non-profit Organization", Journal of Business Ethics, Vol. 75, pp. 115-135.

Lam, A.Y.C., Lau, M.M. and Cheung, R. (2016), "Modelling the relationship among green perceived value, green trust, satisfaction, and repurchase intention of green products", Contemporary Management Research, Vol. 12 No. 1, pp. 47-60.

Lee, S., Phau, I., Hughes, M., Li, I.F. and Quintal, V. (2016), Heritage Tourism in Singapore Chinatown: A Perceived Value Approach to Authenticity and Satisfaction, Journal of Travel and Tourism Marketing, Vol. 33 No. 7, pp. 981-998.

Lam, S.Y., Shankar, V., Erramilli, M.K. and Murthy, B. (2004), "Customer value, satisfaction, loyalty, and switching costs: an illustration from a business-to-business service context", Journal of the Academy of Marketing Science, Vol. 32 No. 3, pp. 293-311.

Lee, C.K., Yoon, Y.S. and Lee, S.K. (2007), "Investigating the relationships among perceived value, satisfaction and recommendations: the case of Korean DMZ", Tourism Management, Vol. 28, pp. 204-214.

Lee, R. and Neale, L. (2012), "Interactions and consequences of inertia and switching costs", Journal of Services Marketing, Vol. 26 No 5, pp. 365-374.

Lin, J-S, C. and Lin, C-Y. (2011), "What makes service employees and customers smile", Journal of Service Management, Vol. 22 No. 2, pp. $183-201$.

Liu, M.W. and Keh, H.T. (2015), "Consumer delight and outrage: scale development and validation”, Journal of Service Theory and Practice, Vol. 25 No. 6, pp. 680-699.

Loureiro, S.M.C., Miranda, F.J. and Breazeale, M. (2014), "Who needs delight?", Journal of Service Management, Vol. 25 No. 1, pp. 101-124.

Maduku, D. (2015), "An empirical investigation of students' behavioural intention to use e-books", Management Dynamics, Vol. 24 No. 3, pp. 2-20. 
Makanyezaa, C., Macheyo, R. and du Toit, F. (2016), "Perceived product necessity, perceived value, customer satisfaction and affective attitude: an integrative model". Journal of African Business, Vol. 17 No 1, pp. 69-86.

Manoj, E. and Sahadev, E.S. (2011), "Role of switching costs in the service quality, perceived value, customer satisfaction and customer retention linkage", Asia Pacific Journal of Marketing and Logistics, Vol. 23 No. 3, pp. 327-345.

MarketLine. (2016), 'South Africa - Mobile Phones'. [Online] Available at: www.marketlineinfo.com (accessed 11 September 2016).

Matzler, K., Strobl, A., Thurner, N. and Füller, J. (2015), "Switching experience, customer satisfaction, and switching costs in the ICT industry", Journal of Service Management, Vol. 26 No. 1, pp. 117-136.

Meng, S.M., Liang, G.S. and Yang, S.H. (2011), "The relationships of cruise image, perceived value, satisfaction, and post-purchase behavioral intention on Taiwanese tourists", African Journal of Business Management, Vol. 5 No. 1, pp. 19-29.

Mohsan, F., Nawaz, M.M., Khan, M.S., Shaukat, Z. and Aslam, N. (2011), "Impact of customer satisfaction on customer loyalty and intentions to switch: evidence from banking sector of Pakistan", International Journal of Business and Social Science, Vol. 2 No. 16 , pp. 263-270.

Newton, J.D., Newton, F.J. and Ewing, M.T. (2014), "The dimensional salience solution to the expectancy-value muddle: An extension". Psychology and Health, Vol. 29 No 12, pp. $1458-1475$.

Nunkoo, R. (2016), "Toward a more comprehensive use of social exchange theory to study residents' attitudes to tourism", Procedia Economics and Finance, Vol. 39, pp. 588-596.

Nyadzayo, M. (2010), The mediating role of customer relationship management on customer retention at selected motor vehicle dealership in the Buffalo City Municipality. Unpublished MCom dissertation. University of Fort Hare, South Africa.

Oliver, R.L. (1989), "Processing of the satisfaction responses in consumption: a suggested framework and research propositions", Journal of Consumer Satisfaction, Dissatisfaction and Complaining Behavior, Vol. 2 No. 1, pp. 1-16.

Pallant, J. (2013), SPSS Survival manual: a step by step guide to data analysis using IBM SPSS. 6th ed. McGraw-Hill: Maidenhead. 
Paul, J., Modi, A. and Patel. J. (2016), "Predicting green product consumption using theory of planned behaviour and reasoned action", Journal of Retailing and Consumer Services, Vol. 29, pp. 123-134.

Ramseook-Munhurrun, P., Naidoo, P. and Lukea-Bhiwajee, S.D. (2009), "Employee perceptions of service quality in a call centre", Managing Service Quality: An International Journal, Vol. 19 No 5, pp. 541-557.

Raza, M.A., Siddiquei, A.N., Awan, H.M. and Bukhari, K. (2012), "Relationship between service quality, perceived value, satisfaction and revisit intention in hotel industry", Interdisciplinary Journal of Contemporary Research in Business, Vol. 4 No. 8, pp. 788-805.

Razzaque, M.A. and Boon, T.G. 2003, "Effects of dependence and trust on channel satisfaction, commitment and cooperation". Journal of Business-to-Business Marketing, Vol. 10 No 4, pp. 23-45.

Roberts-Lombard, M. (2013), "The recruitment market practices of travel agencies in the Gauteng province of South Africa: What is the status quo?", African Journal of Marketing Management, Vol. 5 No 1, pp. 1-19.

Schneider, B. and Bowen, D.E. (1999), "Understanding customer delight and outrage", Sloan Management Review, Vol. 41 No. 1, pp. 35-45.

Sheth, J.N., Newman, B. and Gross, B. (1991), "Why we buy what we buy: a theory of consumption values", Journal of Business Research, Vol. 22 No. 2, pp. 159-170.

South Africa Info. (2016), 'South Africa's telecommunications' [Online] available at: http://www.southafrica.info/business/economy/infrastructure/telecoms.htm\#.VEQof B97IU (accessed 27 September 2016).

Southey, G. (2011), "The Theories of Reasoned Action and Planned Behaviour Applied to Business Decisions: A Selective Annotated Bibliography", Journal of New Business Ideas and Trends, Vol. 9 No 1, pp. 43-50.

Stavros, C. and Westberg, K. (2009),"Using triangulation and multiple case studies to advance relationship marketing theory", Qualitative Market Research: An International Journal, Vol. 12 No 3, pp. 307-320.

Theron, E., Terblanche, N.S. and Boshoff, C. (2012), "A managerial framework for relationship management in the business-to-business financial services industry", Management Dynamics, Vol. 21 No 4, pp. 31-42.

Thrasher, R.G., Andrew, D.P.S. and Mahony, D.F. (2011), "The Efficacy of a Modified Theory of Reasoned Action to Explain Gambling Behavior in College Students", Journal of Gambling Studies, Vol. 27, pp. 499-516. 
Torres, E.N. and Kline, S. (2013), "From customer satisfaction to customer delight: creating a new standard of service for the hotel industry", International Journal of Contemporary Hospitality Management, Vol. 25 No. 5, pp. 642-659.

Torres, E.N., Fu, X and Lehto, X. (2014), "Are there gender differences in what drives customer delight?", Tourism Review, Vol. 69 No. 4, pp.297-309.

Trasorras, R., Weinstein, A. and Abratt, R. (2009), "Value, satisfaction, loyalty and retention in professional services", Marketing Intelligence and Planning, Vol. 27 No. 5, pp. 615-632.

Tsai, W.C. (2001), "Determinants and consequences of employee displayed positive emotions", Journal of Management, Vol. 27 No. 4, pp. 497-512.

Tsai, W.C. and Huang, Y.M. (2002), "Mechanisms linking employee affective delivery and customer behavioral intentions", Journal of Applied Psychology, Vol. 87 No. 5, pp. 1001-1008.

Yeh, Y-P. (2016),"Market orientation and service innovation on customer perceived value", Management Research Review, Vol. 39 No 4, pp. $449-467$.

Yu, H.S., Zhang, J.J., Kim, D.H., Chen, K.K., Henderson, C., Min, S.D. and Huang, H. (2014), "Service quality, perceived value, customer satisfaction, and behavioral intention among fitness center members aged 60 years and over", Social Behavior and Personality, Vol. 42 No. 5, pp. 757-768.

Van Vuuren, T. (2011), Customer loyalty in an optometric practice - a case study perspective. Unpublished MCom dissertation. University of Johannesburg, South Africa.

Vera, J. (2015), "Perceived brand quality as a way to superior customer perceived value crossing by moderating effects", Journal of Product and Brand Management, Vol. 24 No. 2, pp. $147-156$.

Wang, J.L., Jackson, L.A., Gaskin, J. and Wang, H.Z. (2014), "The effects of Social Networking Site (SNS) use on college students' friendship and well-being", Computers in Human Behavior, Vol. 37, pp. 229-236.

Wu, H.C. (2014), "The effects of customer satisfaction, perceived value, corporate image and service quality on behavioral intentions in gaming establishments", Asia Pacific Journal of Marketing and Logistics, Vol. 26 No. 4, pp. 540-565. 